\title{
Molecular characterization of enterohemorrhagic $E$. coli 0157 and 0153 isolated from tissue camel and human stool samples in Al-Diwaniyah, Iraq
}

\author{
S.F. Klaif ${ }^{1}$, Z.F. Saleh ${ }^{1}$, M.T. Hussein ${ }^{2}$, A.A. Jawad ${ }^{1}$ and M.S. Jawad $^{3 *}$ \\ ${ }^{1}$ Unit of Zoonotic Disease Research, ${ }^{2}$ Department of Microbiology, ${ }^{3}$ Department of Anatomy, \\ College of Veterinary Medicine, University of Al-Qadisiyah, Al-Diwaniyahi, Iraq, "email: Sabafk28@yahoo.com
}

(Received May 18, 2018; Accepted August 1, 2018)

\begin{abstract}
The present study aimed to describe the genetic relationships of zoonotic characterization of Escherichia coli isolated from human and livestock camel clinical infection. The study includes collected (50) meat of camel and (50) stool human samples. These samples were foreword to traditional bacterial isolation and identification using enrichment culture method and biochemical tests, then confirmed by PCR technique based on Gyr B gene Escherichia coli and DNA sequencing was done on some positive isolates. The results show that Escherichia coli were isolated from animals at $42(84 \%)$ and 39 (78\%) from human infection. The PCR technique was show highly sensitive and specific confirmative detection of Escherichia coli the positive results into $40(95 \%)$ meat sample of camel, and $35(89.7 \%)$ stool sample of a human. To evaluate of Virulence E.coli, we used specific virulence hlyA gene from NCBI-GenBank, published sequence of E. coli hly A gene (Genbank code: X94129.1) and the results show high of presence of virulence gene hly A in camel in percentage (19) $45 \%$ than of virulence gene in human (15) 38\%. DNA sequencing of a partial sequence of GyrB gene was shown highly homology sequence identity with NCBI-Blast Escherichia coli strain $0157 \mathrm{H} 7$ isolates from human and $\mathrm{O} 153 \mathrm{H} 3$ from the camel. The phylogenetic analysis was shown there is clear genetic similarity at between human and animal's $E$. coli isolates and then the gene sequence deposited into NCBI-Genbank accession numbers (MG560867.1, MG560866.1). Also, study design for detection of some virulence gene hly A Escherichia coli. In conclusion, there prevalence E. coli in humans and camel. Therefore, it is essential to define the role of animals as an important source for the distribution of pathogen related to public health. Our study found gyrB gene sequence could be used for identification and making a phylogenetic analysis of gyrB nucleotide.
\end{abstract}

Keyword: E. coli $\mathrm{PCR}$ O153H2, O157H7, gyr B, hly A, sequencing and phylogenetic tree Available online at http://www.vetmedmosul.com

$$
\begin{aligned}
& \text { التوصيف الجزيئي لبكتريا الايشريشيا القولونية النزفية } 0157 \text { وO153 المعزولة من لحوم الجمال }
\end{aligned}
$$

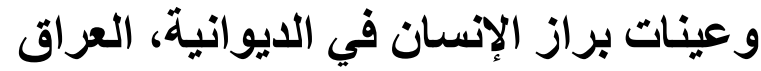

$$
\begin{aligned}
& \text { صبا فلاح كليف'، زينة فؤاد صالح'، مشتاق طالب حسين'، علاء عبد الكاظم جواد' و محمد صبري جواد" } \\
& \text { 'وحدة البحوث و الأمر اض المشتركة، ‘َفرع الأحياء المجهرية البيطرية، ' فرع التثريح والأنسجة، } \\
& \text { كلية الطب البيطري، جامعة القادسية، الديو انية، العراق القاب }
\end{aligned}
$$

هدفت الدر اسة الحالية إلى وصف العلاقة الور اثية للتوصيف الحيو اني المنشأ بين الاشيركيا القولونية المعزولة من العدوى السريرية

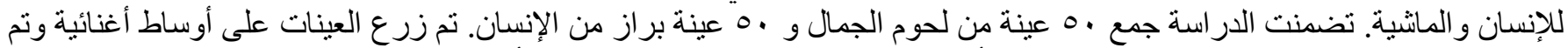

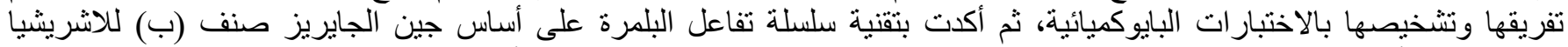

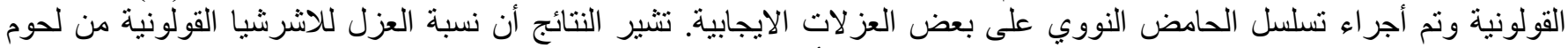

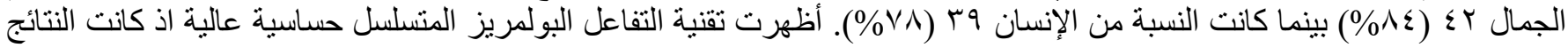




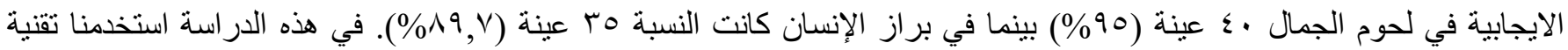

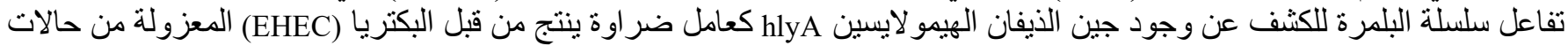

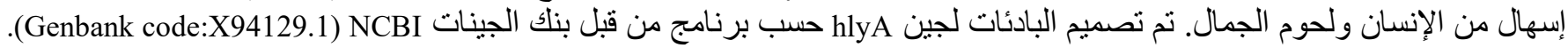

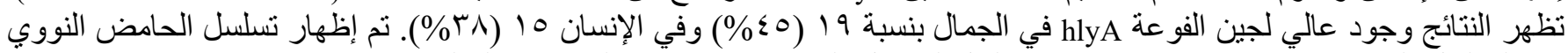

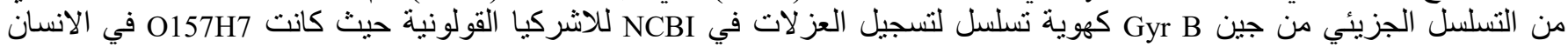

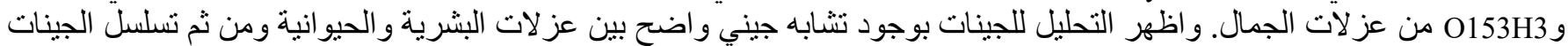

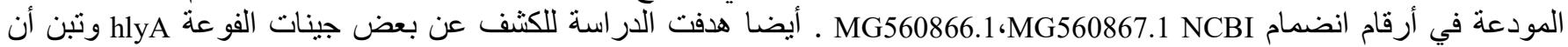

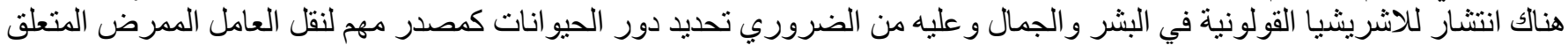

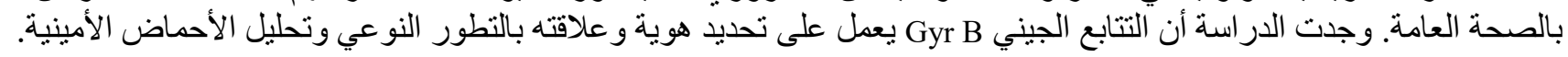

\section{Introduction}

Extra intestinal diseases can be caused by varied strains of E. coli which have the capacity to lysis of RBC of different animals (hemolysis). Camel and other small ruminants are considered the main natural reservoir of $E$. coli and other Enterobacteriaceae pathogens. E. coli have several types of hemolysin related to different pathogroups (1), ̀̀-hemolysin is the best being (2). The four linked genes hly C, A, B, D products are required for the production of $\grave{\alpha}$-hemolysin inactive form (3).

Hly $\mathrm{C}$ protein plays an important role in activation of inactive $\dot{\alpha}$-hemolysin polypeptides by catalysis add of the fatty acid group, hemolysin of $E$. coli is the main virulence factor for some strains of the pathogenic bacteria involved in human and animals extraintestinal diseases like urinary tract infections, peritonitis, meningitis and septicemia (4). $\grave{\alpha}$ - hemolysin secretion is signal peptide-independent and interpose by determinant membranous translocated protocol encoded by hly B, D (5). Enterohemolysin is another hemolysin closely related with E. coli serotype O157, O26, O 111. E. coli O 157:H7 strains caused several types of diseases as hemorrhagic colitis. Cytolysin has activity in several cells of the blood and renal tubular cell (6). Hemolysin owes its name to the fact that it causes hemolysis or lysis of red blood cells, and this is indeed the basis for its most commonly used assay. (The prefix a, that is often omitted nowadays, indicated the extracellular form of the toxin originally). In spite of its name, $\alpha$-hemolysin is widely believed to act mainly by attacking the immune system cells of the host, usually without inducing cell lysis, yet severely impairing their function (7).

HlyA gene composed of a long chain of polypeptides (1024 amino acids) with 31 and 32 is some carbohydrates which are associated. The polypeptide activity damage membrane directly, since changes as mutations as one or two amino acids changes in specific positions render the inactive of protein (8). The gyr B gene is a coding protein called DNA gyrase, a type II DNA topoisomerase. The protein has a great role in DNA multiplication in the bacteria,Sequences of the gyrB gene used in phylogenetic reports of Salmonella spp, Shigella and E. coli (9). Our study found gyrB gene sequence could be used for identification and making a phylogenetic analysis of gyrB nucleotide, this study aimed to isolate and characterize EHEC strains from animal tissue and stool samples to elucidate the extent of food contaminated by camel tissue in Iraq.

\section{Materials and methods}

\section{Samples collection}

One hundred samples divided into fifty tissues (meat) of camel were collected from slaughterhouse of Al-Diwaniyah city, and fifty samples of human suffered from diarrhea in different sites of Al- Qadisyah province. These samples were placed in a cold container and transported to bacteriology Lab, in Veterinary Medicine College for isolationi and definition of E. coli.

\section{Isolation and identification of $E$. coli Bacterial isolation}

$E$. coli was isolated from stool samples and many of the tissues by culture on Brain Heart Infusion Broth (BHIB) agar for overnight at $37^{\circ} \mathrm{C}$. then the bacterial growth were cultured on MacConkey media, Eosin methylene blue (EMB) media, blood agar, and orientation- CHROM agar for overnight for preparation pure $E$. coli colony. Biochemical identification tests (IMViC and TSI) were also used for more detection of Escherichia coli isolates agreement with (10).

\section{DNA extraction of bacteria genome}

$E$. coli genome was extracted by using a special kit called (PrestoTM Mini gDNA Bacteria Kit. Gene aid. the USA) however, the extraction included $1 \mathrm{ml}$ of the new bacterial colony from nutrient broth media and put it in 1.5 $\mathrm{ml}$ microcentrifuge tubes. The centrifuge used to run the tubes for one minute at (10000). After centrifuge finished, the supernatant is produced then it removed. The Nanodrop spectrophotometer was used to testing the concentration DNA and keep in the freezer at $-20^{\circ} \mathrm{C}$. 


\section{Polymerase chain reaction (PCR)}

The specific primer was used in PCR assay to detect $E$. coli the housekeeping gene gyrB, $F$ (GAA GTC ATC ATG ACC GTT CTG CA) and R (AGC AGG GTA CGG ATG TGC GAG CC) (11). With product size $1256 \mathrm{bp}$ and specific virulence gene of hemolysin toxin (hlyA). E. coli hlyA-F forward primer (GGAGTTAGTGCAGCCTCCAG) and hlyA-R reverse primer (ACCACTCTGACTGCGATCAG) 360bp. In NCBIGenBank website used for primers designing under code (Genbank code: X94129.1) through use primer 3 plus design online. Bioneer Company provided the primers at a 360 bp. PCR premix tube consist of Taq DNA polymerase $1 \mathrm{U}$, dNTPs $250 \mu \mathrm{M}$, Trisi-HCl (pH 9.0) $10 \mathrm{mM}, \mathrm{KCl} 30$ $\mathrm{mM}, \mathrm{MgCl} 21.5 \mathrm{mM}$, stabilizer, and tracking dye). PCR reaction was acted by added $5 \mu$ of purified genomic DNA and $1.5 \mu \mathrm{l}$ of $10 \mathrm{pmole}$ of forwarding primer and $1.5 \mu \mathrm{l}$ of 10 pmole of reverse primer to PCR premix tube and complete the volume into the $20 \mu \mathrm{l}$ total volume by deionizer PCR water according to kit instructions. Briefly, it mixed by Exispini vortex centrifuge (Bioneer. Korea). The PCR thermocycler apparatus (Mygene Bioneer. Korea) used to make a reaction. The reaction consists of 30 cycles. The reaction consists of four stages included the first stage is DNA denaturation for one minute at $94^{\circ} \mathrm{C}$, the second stage is primer annealing for one minute at $60^{\circ} \mathrm{C}$, and the third stage is primer extension for one minute at $72^{\circ} \mathrm{C}$. The last stage is extension stage for ten minutes at $72{ }^{\circ} \mathrm{C}$ for gre gene. While in hly $A$ gene was $95^{\circ} \mathrm{C}$ in the initial denaturation for five minutes, next 30 cycles at $95^{\circ} \mathrm{C}$ as denaturation for 30 second, annealing for thirteen second at $58^{\circ} \mathrm{C}$, and extension stage at $72^{\circ} \mathrm{C}$ for one minute and finallyi extensioni for ten minute at $72^{\circ} \mathrm{C}$. The last step, the electrophoresis used to testing PCR products band at a concentration an agarose gel $1.5 \%$, then stained by ethidiumi bromide stain and watch underi UV light.

\section{DNA sequencing}

The sequencing was performed for final diagnosis of E.coli, one isolate was taken from human and one from camel based on Gyr B gene, the PCR product was purified from agarose gel by using (EZ EZ-10 Spin Columni DNA Gel Extraction Kit, Biobasic. Canada). Then purifiedi Gyr B gene was sent to Korea in the Bioneer Company for testing and confirm DNA sequence of the Gyr B gene. The final genomic sequences were submitted in GenBank-NCBI website then alignment was made by search Tool (BLAST) for showing phylogenetic analysis and tree construction by MEGA program.

\section{Results}

Cultural characters of E.coli growth on MacConkey agar pink colonies while some strains show zone $\beta$-hemolysis on blood agar, the metallic green sheen on Eosin-methylene blue agar and Orientation -CHROM agar showed a metallic pink colour (Figure 1).

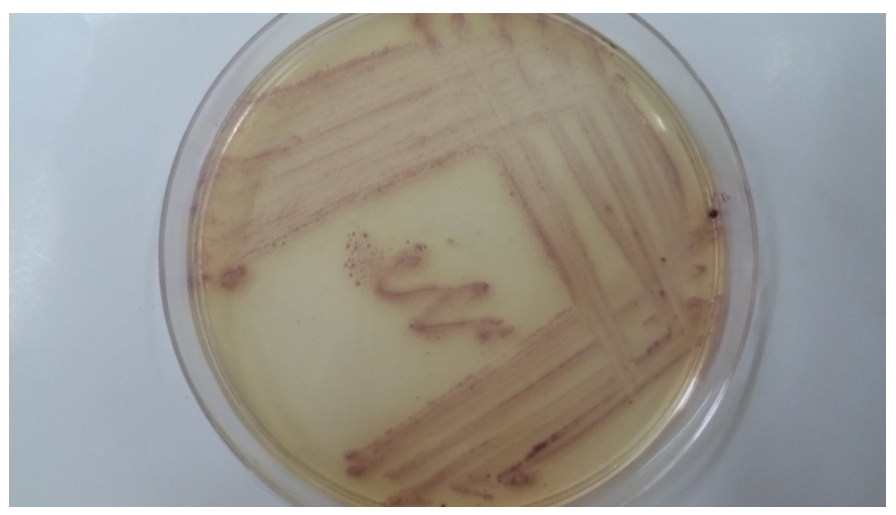

Figure 1: Orientation CHROM agar showed colonies have metallic pink colour.

The results showed that $42(84 \%)$ samples were positive for Escherichia coli from a tissue sample of a camel while positive culture was $39(78 \%)$. Obtain from the stool of human samples (Table 1).

Table 1: E. coli isolates numbers and percentages from the both samples

\begin{tabular}{lccc}
\hline $\begin{array}{l}\text { Types of } \\
\text { samples }\end{array}$ & $\begin{array}{c}\text { Positive } \\
(\%)\end{array}$ & $\begin{array}{c}\text { Negative } \\
(\%)\end{array}$ & Total \\
\hline Tissue of camel & $42(84) \%$ & $8(16) \%$ & $50(100) \%$ \\
Stool of human & $39(78) \%$ & $11(22) \%$ & $50(100) \%$ \\
\hline Total & $81(81) \%$ & $19(19) \%$ & $100(100) \%$ \\
\hline
\end{tabular}

\section{The results of PCR}

The results of PCR technique show 75 (92.5\%) positive samples of $G y r$ B gene, divided into 40 (95\%) tissue sample of camel, and $35(89.7 \%)$ stool sample of a human (Table 2).

Table 2: Isolates number of Escherichia coli which have Gyr B gene

\begin{tabular}{lccc}
\hline $\begin{array}{l}\text { Types of } \\
\text { samples }\end{array}$ & $\begin{array}{c}\text { No. of } \\
\text { E.coli }\end{array}$ & $\begin{array}{c}\text { gyr B } \\
\text { PCR }\end{array}$ & $\begin{array}{c}\text { Percentage } \\
\%\end{array}$ \\
\hline Tissue of camel & 42 & 40 & $95 \%$ \\
Stool of human & 39 & 35 & $89.7 \%$ \\
\hline Total & 81 & 75 & $92.5 \%$ \\
\hline
\end{tabular}

The results of PCR technique show 34 (41.9\%) positive samples of hemolysin toxin gene, divided into19 (45\%) tissue sample of camel, and $15(38 \%)$ stool sample of a human (Table 3). 
Table 3: Isolates number of Escherichia coli which have hemolysin toxin gene (hlyA)

\begin{tabular}{lccc}
\hline $\begin{array}{l}\text { Types of } \\
\text { samples }\end{array}$ & $\begin{array}{c}\text { No. of } \\
\text { E.coli }\end{array}$ & $\begin{array}{r}\text { Result of } \\
\text { hlyA PCR }\end{array}$ & $\begin{array}{c}\text { Percentage } \\
\text { hlyA gene }\end{array}$ \\
\hline Tissue of camel & 42 & 19 & $45 \%$ \\
Stool of human & 39 & 15 & $38 \%$ \\
\hline Total & 81 & 34 & $41.9 \%$ \\
\hline
\end{tabular}

PCR assay results were dependent on the extracted bacterial genomic DNA by using (PrestoTM Mini gDNA Bacteria Kit. Geneaid. USA) this kit was used spin columnbased nucleic acid purification its solid phase extraction method to quickly purify nucleic acids. This method relies on the fact that nucleic acid will bind to the solid phase of silica under certain conditions. Therefore this kit was appeared rapid in 1 hours extraction and simple method for purification of Escherichia coli bacterial genomic DNA from overnight bacterial growth on enrichment BHI broth media at $37^{\circ} \mathrm{C}$ and the agarose gel electrophoresis was appeared, there were sharp gyr $B$ bands without nucleic acid lysis (Figure 2).

PCR amplification of hlyA gene in positive samples was shown clear PCR product bands on agarose gel electrophoresis at $360 \mathrm{bp}$ PCR product (Figure 3).

Two isolates, one from camel while the second isolation from human sequence sent for sequencing were after that submission in NCBI-GenBank database to get accession number codes (MG560867.1, MG560866.1) frequently. DNA sequencing method was performed for phylogenetic confirmative of E-coli on Gyr B detection, phylogenetic analysis, and zoonotic importance (Figure 4 and 5).

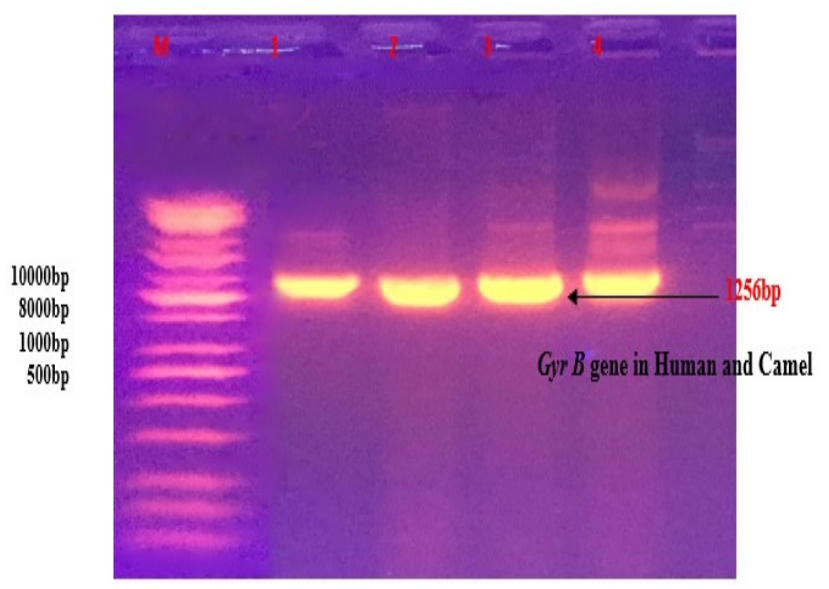

Figure 2: The image shows the PCR product band on gel electrophoresis represent of gyr $B$ gene in E. coli isolates.

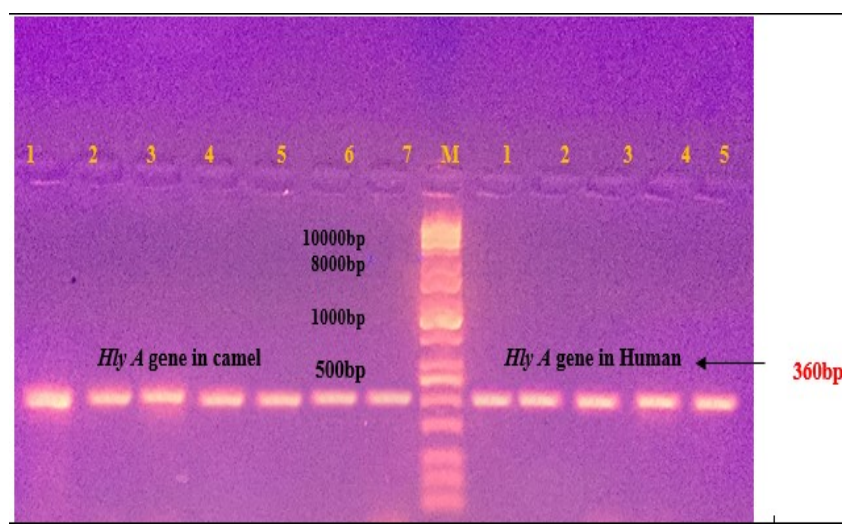

Figure 3: The image was shown the PCR product band that represent a product band of the of Hly A gene in E. coli isolates. Sequencing and phylogenetic analysis.

\section{Discussion}

Enterohemorrhagic Escherichia coli (EHEC) is an important emerging zoonotic foodborne pathogen that can cause gastroenteritis in humans as well as in animal $(11,12)$. The Food contaminated with EHEC is a principal source of infection in humans $(13,14)$.

The results of this study had shown the isolation of $E$. coli hly $A$ gene at percentage 19 (45\%) from tissue camel and,15 (38\%) stool from human isolates. The high prevalence of EHEC in Camel is dependent on various factors, including the hygienic conditions of the farms and abattoirs. Also, surrounding environments can impact the distribution of EHEC in animal faeces, food products, and water samples respectively so that these results appeared the main role of E.coli; our results showed that the proportion of EHEC was higher in faeces (15-17). The pathogenesis of EHEC O157 is associated with several virulence factors, such enterohemolysin (encoded by hlyA) (18).

Used PCR methods by using multiplex PCR technique for detection some genes in $E$. coli in stool samples from many of animals such as sheep, goat, pigs, and cattle. The hemolysin is virulence factor used for cell detachment in vitro (19). The E. coli isolate can production of the hemolysins. Ehx gene or hly gene is very similar to Hly A gene in the function that including calcium ion dependency in the cell (20).

In the phylogenetic-tree analysis of gyrB, E.coli isolated from human and from camel The phylogenetic tree shows high identity of human isolates is similar to $\mathrm{O} 157 \mathrm{H} 7$ which consider virulence strain and zoonotic impotence that may transmitted to animal as well as the E. coli isolates show $\mathrm{O} 153 \mathrm{H} 3$ high similarity with $99 \%$ with $\mathrm{AB} 083866.1$, the strain that coded MG560866.1, a Japan with human resource that mean of zoonotic strain and importance in 
infection to human, while isolate that coded MG560867.1 and recorded as $\mathrm{O} 157 \mathrm{H} 7$ high similarity with $99 \%$ with $\mathrm{CP} 014314.1 \mathrm{O} 157 \mathrm{H} 7$ an USA isolated from camel that mean of zoonotic importance and high virulence in transmission disease.

The percentage of changing of the gene $\operatorname{gyr} B$ is higher than the 16S rRNA region, and all bacterial carry the $\operatorname{gyr} B$ gene. We think gyrB gene have a high capability for identifying microbe generally and bacteria especially. The method is characterized by rapid and high accuracy for identification most genus of the bacteria (21), using of the $\operatorname{gyr} B$ gene is considered a useful method for identification and confirmation species of the bacteria $(22,23)$.

In the end, the PCR is technique have rapidly in the detection of (hlyA) gene. Enterohemorrhagic E. coli have $h l y A$ that important virulence factor wherever isolated from human and camel. The PCR has high specific and high sensitive very useful for detection pathogen.

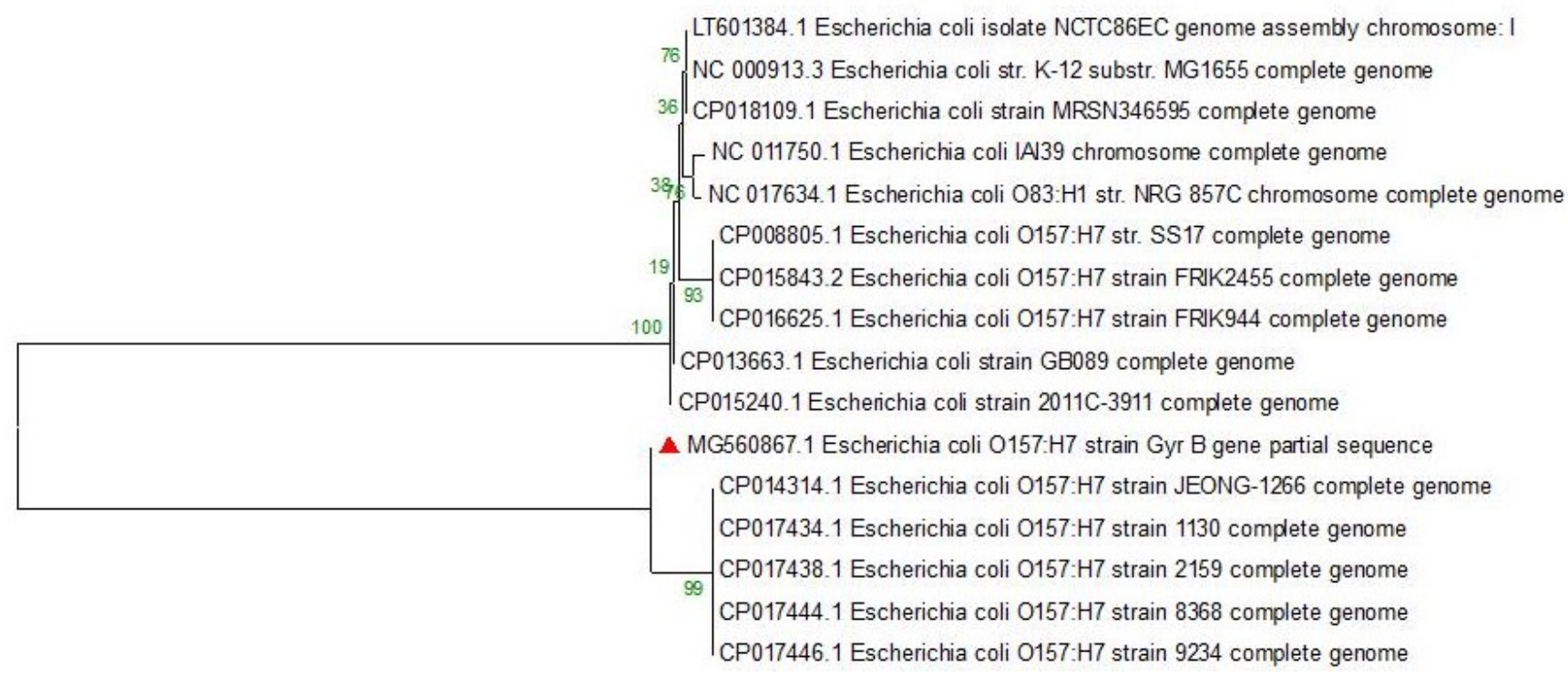

Figure 4: Phylogenetic tree of E.coli strain O157H7which isolated from human.

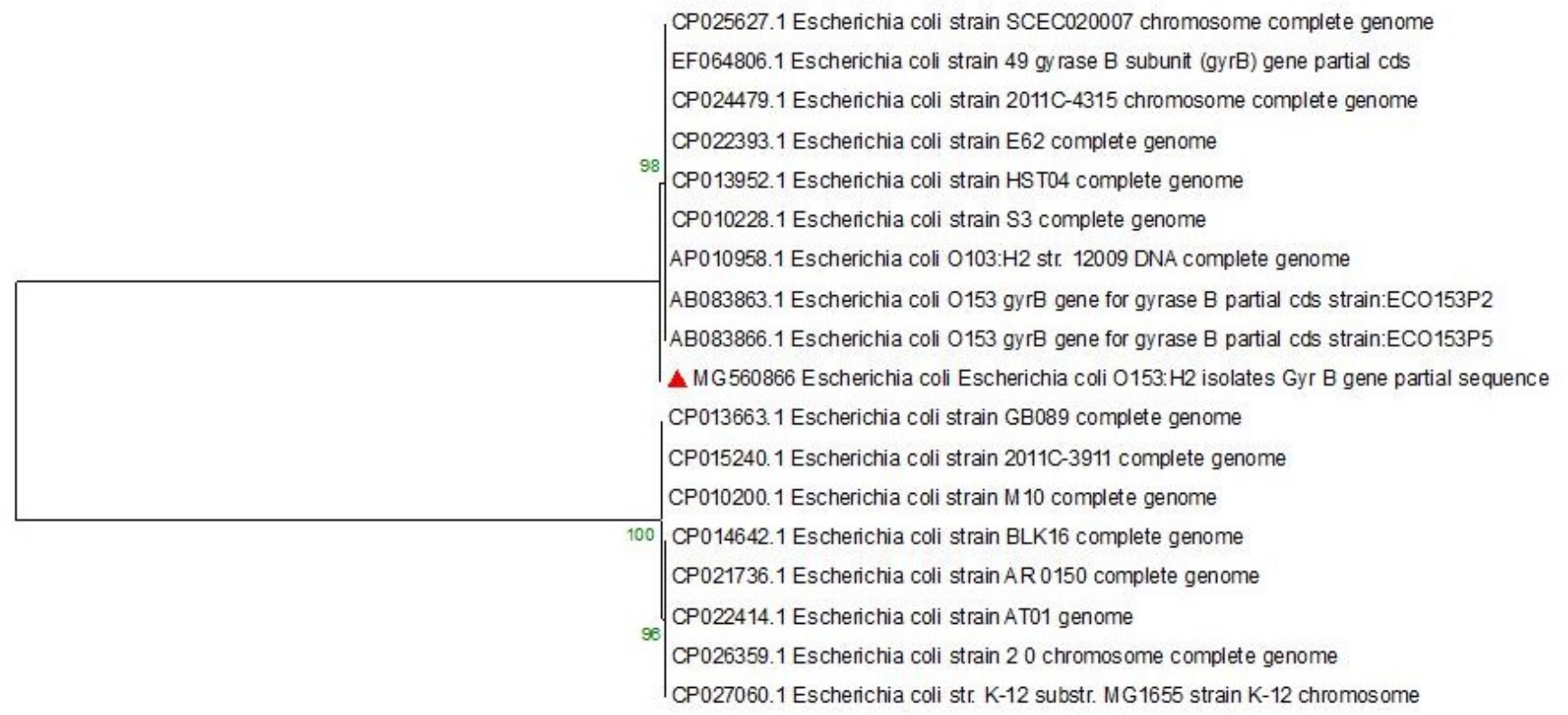

Figure 5: Phylogenetic tree E. coli strain $\mathrm{O} 153 \mathrm{H} 2$ which isolated from camel. 


\section{References}

1. Nataro JP, Bopp CA, Fields PI, Kaper JB, Strockbine NA. Escherichia, Shigella, and salmonella. In: Versalovic J, Carroll K.C, Funke G, Jorgensen J.H, Landry M.L, Warnock D.W, editors. Manual of Clinical Microbiology. Washington: ASM Press; 2011; pp. 603626.

2. Schmidt H, Beutin L, Karch H. Molecular analysis of the plasmidencoded hemolysin of Escherichia coli O157:H7 strain EDL 933. Infect Immun. 1995;63(3):1055-1061.

3. Jeshveen SS, Chai LC, Pui CF, Son R. Optimization of multiplex PCR conditions for rapid detection of Escherichia coli $\mathrm{O} 157: \mathrm{H} 7$ virulence genes. Inter Food Res J. 2012;19(2):461-466.

4. Watt P M and Hickson I D. Structure and function of type II DNA topoisomerases. Biochem J. 1994;303:681-695.

5. Steven MP, Pauline van Diemen M, Dziva F, Jones P W, Wallis T S, Options for the control of enterohaemorrhagic Escherichia coli in ruminants. Microbiol. 2002;148(12):3767-3778.

6. Jeshveen SS, Chai LC, Pui CF, Son R. Optimization of multiplex PCR conditions for rapid detection of Escherichia coli O157: H7 virulence genes. Inter Food Res J. 2012;19(2):461-466.

7. Busch U, Hormansdorfer S, Schranner S, Huber I, Bogner K, Sing A. Enterohemorrhagic Escherichia coli excretion by child and her cat. Emerg Infect Dis J. 2007;13(2):348-349.

8. Cavalieri, SJ, Bohach GA, Snyder IS. Escherichia coli a-hemolysin: characteristics and probable role in pathogenicity. Microbiol Rev. 1984;48:326-343.

9. Fukushima M, Kakinuma K, Kawaguchi R. Phylogenetic analysis of Salmonella, Shigella, and Escherichia coli strains on the basis of the gyrB gene sequence. J Clin Microbiol. 2002;40:2779-2785.

10. Nataro JP, Bopp CA, Fields PI, Kaper JB, Strockbine NA. Escherichia, shigella, and salmonella. In Manual of Clinical Microbiology; Versalovic J, Carroll KC, Funke G, Jorgensen JH, Landry ML, Warnock DW, editors. Washington: ASM Press; 2011. pp. 603-626.

11. Yamamoto S, Harayama S. Phylogenetic analysis of Acinetobacter strains based on the nucleotide sequences of gyr B genes and on the amino acid sequences of their products. Int $\mathrm{J}$ Syst Bacteriol. 1996;46:506-511.
12. Gyles CL. Shiga toxin-producing Escherichia coli: an overview. J Ani Sci. 2007;85(13):e45-e62.

13. Xiong Y, Wang P, Lan R. A novel Escherichia coli O157:H7 clone causing a major hemolytic uremic syndrome outbreak in China. PLoS ONE. 2012;7(4):e36144.

14. Tutenel AV, Pierard D, Van Hoof J, Cornelis M, and De Zutter L. Isolation and molecular characterization of Escherichia coli $\mathrm{O} 157$ isolated from cattle, pigs and chickens at slaughter. Inter J Food Microbiol. 2003;84(1):63-69.

15. Maruzumi M, Morita M, Matsuoka Y, Uekawa A, Nakamura T, Fuji $\mathrm{K}$. Mass food poisoning caused by beef offal contaminated by Escherichia coli O157. Japanese J Infect Dis. 2005;58(6):397.

16. Ateba CN, Mbewe M. Detection of Escherichia coli O157:H7 virulence genes in isolates from beef, pork, water, human and animal species in the northwest province, South Africa: Public health implications. Res Microbiol. 2011;162(3):240-248.

17. Wang J, Shen LP, Liu PH. Study on Escherichia coli O157:H7 among animal and animal's products in Shanghai. Progress Vet Med. 2005;26(4):87-90.

18. Ateba CN, Bezuidenhout CC. Characterization of Escherichia coli O157 strains from humans, cattle and pigs in the North-West Province, South Africa. Inter J Food Microbiol. 2008;128(2):181-188.

19. Law D. Virulence factors of Escherichia coli $\mathrm{O} 157$ and other Shiga toxin-producing E. coli. J Appl Microbiol. 2000;88(5):729-745.

20. Welinder OC, Badenfors M, Cheasty T, Kjellin E, Kaijser B. Genetic profiling of enterohemorrhagic Escherichia coli strains in relation to clonality and clinical signs of infection. J Clin Microbiol. 2002;40:959-964.

21. Peter KF, Michael AH, Karl AB, Steven PD. Detection of Shiga-Like Toxin (stx1 and stx2), Intimin (eaeA), and Enterohemorrhagic Escherichia coli (EHEC) Hemolysin (EHEC hlyA) Genes in Animal Feces by Multiplex PC. Appl Environ Microbiol. 1999;65(2):868872.

22. Marques LR, Abe CM, Griffin PM, Gomes TA. Association between alpha-hemolysin production and HeLa cell-detaching activity in fecal isolates of Escherichia coli. J Clin Microbiol. 1995;33:2707-2709.

23. Shaohui W, Shuxiao Z, Zhe L, Pingping L, Zixue S, JianchaoW. Donghua S, Beibei L, Zhiyong M. Molecular characterization of enterohemorrhagic E. coli $\mathrm{O} 157$ isolated from animal fecal and food samples in eastern China. J Scient World. 2014;1:1-7. 